\title{
Proposal of strain NCIMB 13488 as neotype of Halorubrum trapanicum. Request for an Opinion
}

\author{
W. D. Grant, ${ }^{1}$ A. Oren ${ }^{2}$ and A. Ventosa ${ }^{3}$ \\ Author for correspondence: A. Oren. Tel: +9722658 4951. Fax: +972 26528008. \\ e-mail: orena@shum.cc.huji.ac.il
}

1 Department of

Microbiology and

Immunology, University of

Leicester, Leicester LE1

9HN, UK

2 The Alexander Silverman Institute of Life Sciences and the Moshe Shilo

Minerva Center for Marine

Biogeochemistry,

The Hebrew University

of Jerusalem,

91904 Jerusalem, Israel

3 Departamento de

Microbiología y

Parasitología, Universidad

de Sevilla, 41012 Seville,

Spain

\begin{abstract}
In view of the fact that strain NRC 34021, the designated type strain of Halorubrum trapanicum, is no longer available, strain NCMIB 13488, derived from strain NRC 34021, is proposed as the neotype strain of $H$. trapanicum.
\end{abstract}

Keywords: Halorubrum trapanicum, neotype strain
Halobacterium trapanicum was first isolated by H. F. M. Petter from 'Trapani' salt from a cannery in Bergen, Norway (Petter, 1931). In the course of a recent rearrangement of the taxonomy of the Halobacteriaceae (McGenity \& Grant, 1995), the species was classified in the newly created genus Halorubrum on the basis of $16 \mathrm{~S}$ rRNA comparison, polar lipid composition and additional phenotypic properties. The new species Halorubrum trapanicum with NRC 34021 as type strain was validated in 1996 (Anonymous, 1996).

The proposed type strain NRC 34021 of Halorubrum trapanicum is no longer available, and therefore the present taxonomic status of the species is uncertain (Oren et al., 1997). Its status was discussed in the open meeting of the International Committee on Systematic Bacteriology Subcommittee on the taxonomy of Halobacteriaceae in Jerusalem, Israel, 20 August 1996 (Oren \& Ventosa, 1997). A detailed survey of all currently circulating strains showed that at least some may belong to different genera, including the genus Halococcus (see also the discussion by Tindall, 1992). Thus, strains NCIMB 767 and ATCC 43102 are cocci with identical phenotypic characteristics and polar lipid patterns that are typical for the genus Halococcus. It was noted that the only culture of the type strain may survive in the laboratory of W. D. Grant. The subcommittee recommended that this culture should be deposited in a culture collection without delay, and that Halorubrum ('Halobacterium') trapanicum should be considered a species incertae sedis until the type strain becomes available once more and/or a comparative study of the existing strains is completed.

The surviving culture, derived from the type strain, and kept in the laboratory of W. D. Grant, has now been deposited in the National Collection of Industrial and Marine Bacteria (Aberdeen, UK) as strain NCIMB 13488. The properties of this culture generally agree with the original species description of Halobacterium trapanicum (Elazari-Volcani, 1957). We detected some acid formation (a decrease of $0.5 \mathrm{pH}$ units or more in unbuffered medium containing $0 \cdot 1 \%$ yeast extract and $1 \%$ of the substance tested) on glucose, mannose, galactose, fructose, maltose, sucrose, trehalose and glycerol. The same substrates also stimulated growth in a buffered medium. No acid formation or growth stimulation was observed on rhamnose, arabinose, sorbose, melezitose, ribose, xylose, lactose, raffinose, dextrin, inulin, starch, mannitol or salicin. The original species description (ElazariVolcani, 1957) states that no acids are formed. This discrepancy is probably due to the higher buffer capacity of the medium used in the early studies (containing $1 \%$ peptone) and the more sensitive detection of acid formation in our recent study, using a $\mathrm{pH}$ electrode.

In accordance with Rule $18 \mathrm{c}$ of the International Code of Nomenclature of Bacteria (Lapage et al., 1992), we 
propose strain NCIMB 13488 as the neotype strain of Halorubrum trapanicum, to become the established neotype 2 years after the date of its publication in the IJSB.

\section{Acknowledgements}

We thank Hans G. Trüper (Bonn) for invaluable discussions.

\section{References}

Anonymous (1996). Validation of the publication of new names and new combinations previously effectively published outside the IJSB. List no. 56. Int J Syst Bacteriol 46, 362-363.

Elazari-Volcani, B. E. (1957). Genus XII. Halobacterium ElazariVolcani, 1940. In Bergey's Manual of Determinative Bacteriology, 7th edn, pp. 207-212. Edited by R. S. Breed, E. G. D. Murray \& N. R. Smith. Baltimore: Williams \& Wilkins.

Lapage, S. P., Sneath, P. H. A., Lessel, E. F., Skerman, V. B. D., Seeliger, H. P. R. \& Clark, W. (editors) (1992). International Code of Nomenclature of Bacteria (1990 Revision). Washington, DC: American Society for Microbiology.
McGenity, T. J. \& Grant, W. D. (1995). Transfer of Halobacterium saccharovorum, Halobacterium sodomense, Halobacterium trapanicum NCR 34021 and Halobacterium lacusprofundi to the genus Halorubrum gen. nov., as Halorubrum saccharovorum comb. nov., Halorubrum sodomense comb. nov., Halorubrum trapanicum comb. nov., and Halorubrum lacusprofundi comb. nov. Syst Appl Microbiol 18, 237-243.

Oren, A. \& Ventosa, A. (1997). International Committee on Systematic Bacteriology Subcommittee on the taxonomy of Halobacteriaceae. Minutes of the Meetings, 19 and 20 August 1996, Jerusalem, Israel. Int J Syst Bacteriol 47, 595-596.

Oren, A., Ventosa, A. \& Grant, W. D. (1997). Proposed minimal standards for description of new taxa in the order Halobacteriales. Int J Syst Bacteriol 47, 233-238.

Petter, H. F. M. (1931). On the bacteria of salted fish. Proc $\mathrm{K} \mathrm{Ned}$ Akad Wet Amsterdam Ser B 34, 1417-1423.

Tindall, B. J. (1992). The family Halobacteriaceae. In The Prokaryotes: a Handbook of Bacteria. Ecophysiology, Isolation, Identification, Applications, vol. 1, pp. 768-808. Edited by A. Balows, H. G. Trüper, M. Dworkin, W. Harder \& K.-H. Schleifer. New York: Springer. 